\title{
Janusza Korczaka językowa gra z odbiorcą w racje i emocje - spotkanie dwóch perspektyw
}

\section{Summary}

Janusz Korczak's language game of arguments and emotions played with the recipient - a meeting of two perspectives

Janusz Korczak's literary writing can be perceived as an endeavour to change the world, to make the world fair and marked by greater solidarity. The reading of his texts draws attention of the recipient to the ways in which he characterises children and calls for the necessity of treating them rightly by adults. The author of the article focuses on the persuasiveness of narration, understood as a specific game played with the recipient, and the linguistic features used by Korczak in his literary works. The aim of the article is to show the linguistic features employed by Korczak in presenting theses regarding the situation of children and expressing his beliefs about the protection of children's rights. The author analysed Korczak's literary work entitled When I am Little Again. Stylistically diverse narration is subordinated to one goal - convincement of the recipient to the narrator's arguments. Considered as a whole, the article is an attempt to combine a pedagogical perspective with the poetics of reception.

Keywords: Korczak's literary writing, protector of children's rights, persuasiveness of the message, poetics of reception, narration

Słowa kluczowe: twórczość pisarska Korczaka, obrońca praw dzieci, perswazyjność przekazu, poetyka odbioru, narracja

\section{Wprowadzenie}

Twórczość pisarską Janusza Korczaka można postrzegać jako próbę zmiany świata, uczynienia go sprawiedliwym i solidarnym dla dużych i matych - jak autor określał dorosłych i dzieci. Jego teksty zawierają głęboką wiedzę o dzieciach, są przepełnione ciągłym upominaniem się o respektowanie ich praw, o należne im ze strony dorosłych traktowanie, nacechowane uważnością, rozwagą, miłością i mądrością. W osobie Korczaka dostrzegamy nierozdzielność ról: lekarza, pedagoga, pisarza, społecznika i badacza kultury dziecięcej. Niemożność ich rozgraniczenia jest wyzwaniem dla odbiorcy jego dzieł, przyczyną trudności odczytania sensów. Korczak podobnie pisze w tekstach publicystycznych i literackich, 
trudno postawić ostrą granicę, na przykład w dziele Jak kochać dziecko, będącym swoistym poradnikiem dla matek/rodziców, nadawcą jest doświadczony lekarz, uważny, obiektywny obserwator, sprawozdawca. Cechy te są dobrze widoczne we fragmencie:

Niemowlę bada swe ręce. Prostuje, wodzi w prawo i w lewo, oddala, zbliża, rozstawia palce, zaciska w pięść, mówi do nich i czeka na odpowiedź, prawą chwyta lewą rękę i ciągnie, bierze grzechotkę i patrzy na dziwnie zmieniony obraz ręki, przekłada ją z jednej do drugiej, bada ustami, natychmiast wyjmuje i znów patrzy powoli, uważnie (Korczak 2012: 49).

Narratorowi - lekarzowi w prezentacji świata przedstawionego służą także odmienne środki: figury poetyckie, patos, hiperbolizacja, kontrast i wykorzystanie efektownych pytań retorycznych. Jest to narracja świadoma siebie w sensie literackim i językowym:

Wśród milionów ludzi urodziłaś jeszcze jedno - co? - źdźbło, pyłek - nic.

Takie to kruche, że je zabić może bakteria, która tysiąc razy powiększona jest dopiero punktem w polu widzenia...

Ale to nic jest bratem z krwi i kości fali morskiej, wichru, błyskawicy, Słońca, Drogi Mlecznej. Ten pyłek jest bratem kłosu, trawy, dębu, palmy - pisklęcia, lwiątka, źrebaka, szczenięcia.

Jest w nim, co czuje, bada - cierpi, pragnie, raduje się, kocha, ufa, nienawidzi - wierzy, wątpi, przygarnia i odtrąca.

Ten pyłek ogarnie myślą wszystko: gwiazdy i oceany, góry i przepaście. A czym jest treść duszy, jeśli nie wszechświatem, jeno bez wymiarów?

Oto sprzeczność w istocie człowieczej, powstałej z prochu, w której Bóg zamieszkał (Korczak 2012: 16).

(...) Dziecko i bezmiar.

Dziecko i wieczność.

Dziecko - pyłek w przestrzeni.

Dziecko - moment w czasie (Korczak 2012: 18).

Ostatni z przytoczonych cytatów brzmi jak wiersz powstały z wykorzystaniem zabiegów literackich - anafory i kontrastu.

Zainteresowanie dominującą w tekstach Korczaka tematyką dzieciństwa nie wyklucza refleksji nad wartościami językowymi i literackimi jego utworów oraz sytuowania ich w różnych perspektywach. W większości dzieł Korczaka, powszechnie zaliczanych do literatury dla dzieci, brakuje granic dzielących założonych odbiorców na grupy wiekowe, rejestruje się istnienie tzw. poszerzonego odbiorcy. Autor nie stosuje retoryki dydaktycznej, nieodłącznej cechy książki dziecięcej charakterystycznej dla historycznie wcześniejszej praktyki, a jego teksty cechuje wielowarstwowość - warunek zróżnicowanej konkretyzacji (rozumienia i dookreślania utworu) zależnej od wiedzy oraz doświadczeń życiowych i literackich odbiorców. Utwory bez granic wiekowych w którąkolwiek stronę zwykło się określać mianem wspólnego dobra dzieci i dorosłych. 


\section{Materiał i kierunki analizy}

„Słowo wyzwala człowieka od kontaktów z grupą bezpośrednią i pozwala na kontakt pośredni: dopuszcza interakcję osób w różnym czasie i w odległej przestrzeni, łamiąc w ten sposób najbardziej rygorystyczne ograniczenia (...)" (Grabias 2003: 258). W literaturze materia językowa (wraz z fikcją i uporządkowaniem naddanym) zostaje poddana specyficznym przekształceniom, dalekim od potrzeb komunikacyjnych. Zarysowana we wprowadzeniu tematyka wskazuje na moje zainteresowanie warstwą znaków językowych i literackich wybranych tekstów Korczaka. Podejmuję próbę odczytania na nowo odległego w czasie, powstałego w dwudziestoleciu międzywojennym, w ówczesnym kontekście społeczno-kulturowym, utworu literackiego Janusza Korczaka zatytułowanego Kiedy znów będę mały (1925), posługując się odmiennym kluczem niż stosowany zwykle w interpretacji literatury. Za zasadne uznałam powiązanie tego utworu z aktem komunikacji językowej i podporządkowanie jego analizy kategorii perswazyjności specyficznej dla komunikacji. Pomocna wydała mi się teoria aktów mowy traktująca każdą wypowiedź jako formę celowego działania, przy czym perswazja, bez negatywnych konotacji, rozumiana najogólniej jako wpływanie na odbiorcę, nakłanianie go do zmiany postaw/działań, jest częścią funkcji impresywnej (konatywnej) tekstu.

Jednym z możliwych sposobów rozumienia dyskursu jest postrzeganie go jako zdarzenia komunikacyjnego, przykład użycia języka przez człowieka, który chce przekazać określone myśli i przekonania i/lub wpłynąć na słuchaczy (Lisowska-Magdziarz 2006: 9). Jeżeli uznać, że Korczak był przede wszystkim żarliwym obrońcą praw dzieci, do czego wykorzystywał wszystkie dostępne sposoby, to zasadna staje się próba poszukiwania środków perswazyjnych w utworze literackim jego autorstwa. Proponuję spotkanie dwóch perspektyw: pedagogicznej i poetyki odbioru (a może nawet szerzej - teorii literatury), przy założeniu analizowania powieści Kiedy znów będę mały jako swego rodzaju językowej „gry w racje i emocje” (określenie perswazji podaję za Jerzym Bralczykiem (2004: 18)) między dwiema stronami: nadawcą i wirtualnym odbiorcą. W analizie wykorzystałam środki perswazji zaczerpnięte z koncepcji Grażyny Habrajskiej (2005).

\section{W stronę gatunku}

Zdaniem Teresy Dobrzyńskiej tekst „oznacza z reguły wypowiedzi całościowe, traktowane jako pełny wyraz intencji komunikacyjnej mówiącego. Jest to więc zamknięty układ znaczący - układ, którego elementy poddane są określonemu uporządkowaniu” (Dobrzyńska 2001: 293). Sens tekstu zależy od granic komunikatu i wewnętrznych relacji wiążących elementy składowe. Tekst wolno traktować jako realizację schematu gatunkowego. Szkic powieściowy Kiedy znów będę mały jest rozwinięciem wcześniejszego utworu Korczaka pod tytułem Feralny tydzień, wydanego w 1914 r. razem z tekstami Bobo i Spowiedź motyla ${ }^{1}$. Wspólny jest motyw ciągu zdarzeń skupionych wokół głównego bohatera, ucznia

\footnotetext{
1 Warto podkreślić zasługi Marka Michalaka, zaangażowanego orędownika praw dzieci, Rzecznika Praw Dziecka w latach 2008-2018, w upowszechnianiu dorobku Korczaka. Z jego inicjatywy nastąiło
} 
szkoły podstawowej. Kiedy znów będę mały staje się jednak utworem bardziej złożonym wobec pierwowzoru, $\mathrm{z}$ bogatszą linią narracji i rozwiniętą charakterystyką stanów świadomości bohaterów.

Powieść zaczyna się jak baśń sceną nieoczekiwanego, fantastycznego spotkania narratora (dorosłego) z krasnoludkiem, ukazanym ze wszystkimi zwyczajowymi atrybutami:

A gwiazdka płynie przez ciemność i coraz bliżej - do mnie. Już koło łóżka, już na poduszce. Patrzę - a to maleńka latarka. A na poduszce stoi mały człowieczek... A na głowie ma czerwony, wysoki kapelusz. I siwą brodę. No, krasnoludek. Tylko zupełnie mały - jak palec. - Jestem. Uśmiecha się i czeka (Korczak 1983: 13, 14).

Opowiadanie o przygodach narratora-bohatera nie ma charakteru powieści przygodowej, w wątłej fabule brakuje niezwykłych zdarzeń. Całość tylko pozornie jest baśnią z motywem krasnoludka jako magicznego sprawcy spełnionej prośby narratora - zamiany na pewien czas dorosłego w dziecko. Realizacja życzenia - powrót do dzieciństwa jest $\mathrm{w}$ warstwie fabularnej przykładem realizmu w kostiumie fantastyki, tym razem bez dobrego zakończenia właściwego klasycznym bajkom:

Osaczony ze wszystkich stron. Wszędzie złe słowa, złe spojrzenia, zapowiedź jeszcze groźniejszego. (...) Niegodny, występny, wyklęty, skłócony z życiem. Wszystko porzuciło. Wszędzie zdrada (Korczak 1983: 213, 214).

Osamotniony, niezrozumiany przez wszystkich chłopiec, rozgoryczony i z poczuciem przegranej, prosi krasnoludka o powrót do stanu bycia dorosłym i prośba zostaje spełniona.

Charakterystyka gatunkowa jest zawarta w utworze bezpośrednio, zasadnicza część powieści zostaje bowiem poprzedzona podwójną dedykacją, skierowaną do „dorosłego" i do „młodego czytelnika”:

W powieści tej nie ma ciekawych przygód. Jest to próba powieści psychologicznej.

Nie psychologiczna, że o psach. Nie psy, ale jeden tylko Łatek.

A że po grecku: psyche znaczy - dusza.

Mówi się tu, co się dzieje w duszy człowieka: o czym myśli, co czuje (Korczak 1983: 5).

Podzielona na dwie odrębne części dedykacja z zamierzoną autotematycznością (wypowiedź o dziele w samym dziele) jest jednocześnie zapowiedzią podwójnej perspektywy lekturowej, znacząco różnych odczytań sensów przez dorosłego i dziecięcego odbiorcę.

uwspółcześnione opracowanie wielu dzieł pisarza i zamieszczenie ich na stronach internetowych Rzecznika Praw Dziecka. 


\section{Między odbiorcą wirtualnym a doświadczeniem interpretatora}

Ograniczenia objętości artykułu wiążą się z koniecznością wyboru, a tym samym - rezygnacji z określonych treści, dlatego w prezentacji teoretycznoliterackiego kontekstu rozważań o odbiorcy wirtualnym ograniczam się do wybranych tez, które stały się inspiracją zainteresowania utworem literackim Janusza Korczaka. Do nich zaliczam m.in. propozycję Janusza Głowińskiego usytuowania poetyki odbioru wśród pytań o to, jak struktura utworu (gatunek, temat, styl) określa rolę odbiorcy (a także - jak dzieło projektuje jego zachowania) i jak wymagania odbiorcy (zamówienia społeczne) wpływają na kształt dzieła (Głowiński 1998). Należy nadmienić, że postrzeganie dzieła w perspektywie odbiorcy jest mocno utrwalone w polskiej tradycji literaturoznawczej (por. Głowiński 1977, 1998; Handke 1982). W teorii Rolanda Barthes’a podkreśla się relację tekst-czytelnik, jego aktywność lekturową, „niezmierzony sens dzieła” i każdorazowe jego czytanie jako ,produkcję” (cyt. za: Mitosek 1983: 254-255). Ten sposób rozumienia roli odbiorcy w tekście bliski jest teorii Umberta Eco, który dostrzegał w odczytaniu akt arbitralny, otwierający nieskończoną perspektywę odczytań alternatywnych, gdzie tekst staje się dziełem otwartym (Eco 1994). „W opowiadaniu jednak zawsze istnieje czytelnik i ten czytelnik jest podstawowym składnikiem nie tylko procesu opowiadania, ale i samej opowieści” (Eco 1995: 5), autor wraca do czytelnika jako elementu struktury utworu, by rozwinąć motyw czytelnika modelowego, który „,respektuje reguły gry” i „gotów jest do gry zasiąść" (Eco 1995: 15).

Percepcja świata przedstawionego dzieła, z całą jego złożonością, jest dla odbiorcy empirycznego, w indywidualnej konkretyzacji, zadaniem i jednocześnie wyzwaniem, szczególnie w sytuacji gdy czas powstania utworu i czas jego odbioru jest odległy. Dzieło wytrącone z położenia historycznego i odniesione do innych warunków społeczno-literackich ulegnie odmiennemu odczytaniu. „Interpretacja zatem to zarówno inicjowanie nowych pytań poprzez osadzenie tekstu w nowym kontekście, jak wypowiadanie pytań stawianych przez tekst w nowym »języku«. Obie te czynności - łącznie - zakreślają horyzont powinności interpretatora. Interpretacja tekstu jest nieodłącznie wpisana w jego odbiór" (Rewers 1997: 79). Wskazywanie ewentualnych możliwych relacji wewnątrztekstowych, ogląd szeroko rozumianych cech stylu podporządkowanych zabiegom perswazyjnym na przykładzie wybranej powieści Korczaka jest moim doświadczeniem w roli interpretatora. Akt lektury jest każdorazowo doświadczeniem podmiotowym. „Każde czytanie jest niepowtarzalne, nieodwracalne i nie podlega obiektywizacji, będąc swoistym procesem rozumienia siebie i tekstu, a ściślej - zetknięciem się subiektywnej perspektywy czytelniczej i perspektywy innego. Należy przez to rozumieć, iż jednostkowe zaangażowanie wobec jednostkowego dzieła jest etyczną, bo odpowiedzialną odpowiedzią" (Włodarczyk 2014: 30). 


\section{Perswazyjność tekstu literackiego i jej granice}

W obszernej polskiej literaturze przedmiotu dotyczącej perswazji, manipulacji językowej oraz szerzej - intencji komunikującego (por. Laskowska (red.) 1999; Lewiński 2001; Lubaś 2006; Mosiołek-Kłosińska, Zgółka (red.) 2003) autorzy są zgodni, że komunikatowi perswazyjnemu zawsze towarzyszy chęć wywołania zmiany u odbiorcy, mimo że jedni akcentują chęć zmiany postaw, inni - postaw i przekonań, a jeszcze inni - zachowań (Tokarz 2003: 25). Tytuł niniejszego artykułu nawiązuje do tezy Jerzego Bralczyka, że zazwyczaj teksty perswazyjne odwołują się do sfer: racji, emocji oraz norm; autor nazywa ten toczący się we wszystkich sferach proces komunikacyjną ,grą nadawcy z odbiorcą w racje i emocje" (Bralczyk 2004: 18). Podkreśla, że obie strony mają tylko częściową świadomość tej gry.

Za badawczo zasadne uważam sprawdzenie, na ile możliwe jest wykorzystanie kategorii perswazyjności w analizie narracji w powieści Kiedy znów będę mały, jakie stosuje się sposoby przekonywania odbiorcy, czyli próby zmiany jego wiedzy, postaw, oraz gdzie są granice tego zabiegu przy świadomości różnicy przekazów. Narracja jest tworzeniem znaczeń i jednocześnie tworem artystycznym; zapożyczając określenie od Anny Wierzbickiej - „modelowaniem myśli w słowach” (Wierzbicka 1969: 11). Narrator, opowiadając i opisując świat przedstawiony, kreuje go i nadaje mu empiryczne cechy prawdziwości. Analizując tekst Korczaka, podejmuję próbę przyjrzenia się zabiegom stylistycznym i konstrukcyjnym (wobec wewnątrztekstowych relacji), jakich dokonuje autor, aby za pomocą elementów świata przedstawionego oraz ich wzajemnych układów przekonać odbiorcę do swoich racji obrońcy praw dzieci, a jednocześnie poruszyć emocje, odwołać się do założonej wrażliwości czytelników. Propozycja mojego odmiennego odczytania powieści Korczaka jest więc skupiona wokół następujących pytań: Jaka jest konstrukcja narratora-perswadora? Jakie obrazy dzieciństwa i sytuacji dziecka wyłaniają się w badanej opowieści? W jaki sposób, przy użyciu jakich środków narrator angażuje mentalnie i emocjonalnie odbiorcę?

Przyjmuję za Grażyną Habrajską, że perswazja ,jest to uświadomione przez obserwatora działanie werbalne nadawcy, dążące do zmiany postawy odbiorcy" (Habrajska 2005: 108). „Nadawca, decydując się na zastosowanie wypowiedzi perswazyjnej, zakłada nieodpowiedniość między układem informacyjnym lub układem aksjologicznym odbiorcy a treścią wypowiedzi, co staje się punktem wyjścia do poszerzenia informacji i utrzymania spójności układu aksjologicznego odbiorcy" (Habrajska 2005: 109). Etap tzw. perswazji zewnętrznej, związany z określeniem grupy perswazyjnej, nie jest wobec analizowanego utworu literackiego możliwy, ponieważ wiedza odbiorcy wirtualnego o obiekcie perswazji oraz jego emocjonalnym stosunku nie jest podmiotowi narracji znana. Można jedynie zakładać ogólną znajomość kontekstu kulturowego elementów świata przedstawionego ukazanych w powieści, jak role społeczne bohaterów, sytuacje w rodzinie, szkole, na ulicy itp. Dalszym etapem jest budowanie więzi z odbiorcą, które odbywa się w trzech kierunkach: kreowania dyspozycji odbiorcy do przyjęcia perswazji (np. przez zaintereso- 
wanie tematem), przygotowania emocjonalnego i kreowania wizerunku nadawcy. Fabułę powieści Korczaka stanowi ciąg zdarzeń skupionych wokół głównego bohatera-narratora, którym jest dorosły w ciele dziecka, doświadczający powtórnie zwyczajnych sytuacji i emocji ucznia, syna, brata, kolegi. Dowartościowanie określonego już wcześniej tematu dzieciństwa staje się możliwe dzięki rozwiniętemu realizmowi opisanych zdarzeń i zróżnicowaniu środków narracyjnych.

Interesującym poznawczo zabiegiem jest analizowanie powieściowego portretu perswadora. Kreowanie portretu perswadora (nadawcy) w perswazji sprowadza się - zdaniem Grażyny Habrajskiej - do podkreślenia jego kompetencji, bazowania na szacunku w stosunku do pełnionej przez nadawcę roli społecznej, do eksponowania jego walorów etycznych oraz do budowania więzi JA i TY na zasadzie nawiązania kooperacji (Habrajska 2005: 112). Zajmę się tym, w jaki sposób te ustalenia sformułowane wobec realnych podmiotów komunikacji mogą być przydatne w charakterystyce narratora-perswadora analizowanej powieści Korczaka. Narratorem jest mężczyzna w dojrzałym wieku, na co wskazują opisywane przez niego problemy zdrowotne, nauczyciel (wybór takiej profesji w założeniu powinien przekładać się na większe zaufanie społeczne, lepszą znajomość dzieci), a jednocześnie dziecko w wielu rolach - syna, brata, ucznia szkoły podstawowej i kolegi. W kreowaniu wizerunku perswadora dostrzegam dwa dopełniające się zabiegi: dorosły narrator odwołuje się do bogatych doświadczeń i wiedzy, podkreśla własne kompetencje nauczyciela, a tym samym nawiązuje do szacunku wynikającego z odgrywanej roli społecznej, natomiast wizerunek dziecięcego narratora jest budowany na nieporadności, prostocie, naiwności chłopca i jego bezsilności wobec napotykanych sytuacji. Jednocześnie jego zachowanie, popełniane błędy, niesprawiedliwość, z jaką się na co dzień spotyka, mocno przeżywane radość i smutek, jakie stają się jego udziałem - to wszystko ma emocjonalnie poruszyć odbiorcę, pozytywnie nastawić do chłopca (i szerzej - do dzieci). Mamy tu do czynienia z tzw. perswazją przekonującą, w której ,zakłada się, że odbiorca (słuchacz) jest jednostką aktywną intelektualnie, a nadawca ma uczciwe intencje i zamiary" (Korolko 1990: 30).

Kiedy byłem dorosły, widząc śnieg już myślałem, że będzie błoto, czułem wilgotne obuwie i - czy węgła wystarczy na zimę? I radość - ona także była - ale przysypana popiołem, zakurzona, szara. Teraz czuję tylko białą, przejrzystą, oślepiającą radość. Że co? Że nic: śnieg! (Korczak 1983: 68).

I znów. To niegłupia sobie, dziecinna zabawa. Wykryć tajemnicę, znaleźć ukryte, pokazać, że się nie da schować, by znaleźć nie można. Im trudniej zdobyć, tym milsze zwycięstwo. Czy prawda dorosłych, odkrycie, wynalazek, poznanie - czy lalka w garnku albo pod poduszką. Cała przyroda - to Irenka ukrywająca lalkę, a w mozole szukająca ludzkość - to ja, mały chłopak. Tam zająca goniłem szybkością nóg i sprawnością biegu, tu chwytam lalkę domyślnością, czujnością, uporem. Cóż innego w życiu robimy, co czyni ludzkość cała? Zające gonimy i szukamy lalek (Korczak 1983: 63). 
Należy podkreślić współpodmiotowość nadawcy i odbiorcy poprzez zastosowanie form pierwszej osoby liczby mnogiej (,gonimy”, „,szukamy”). Połączenie dorosłego narratora (z jego pamięcią przeszłości, dystansem, rozwagą), który nieoczekiwanie znajduje się w ciele chłopca zafascynowanego otaczającym światem, skorego do żartów, żądnego biegu, zmiany, a jednocześnie nieśmiałego, wycofanego, daje narratorowi możliwość nieustannego oscylowania między dziecięcym a dorosłym opowiadaniem/ocenianiem z przewagą głosu dziecka. Wtedy uaktywniają się język zbliżony do opisu codziennego doświadczenia, zapis myślenia stylizowany na mowę codzienną, w której dominują: uproszczona składnia, powtarzalność konstrukcji syntaktycznych, powielanie spójników, wielość równoważników, elipsy, naturalność, prostota i potoczność:

I tak mi się zdaje, że siedzę sam jeden w polu, a tu noc i mróz, i jestem sam jeden, i boso, i głodny. I wilki wyją. I zimno. I strach. I już cały drętwieję (Korczak 1983: 99).

Zdarzenia, dialogi stają się podstawą do stawiania tez, uogólnień dotyczących dzieciństwa i trudnych sytuacji dzieci, naznaczonych niesprawiedliwym, krzywdzącym traktowaniem, lekceważeniem ich uczuć i potrzeb, obojętnością, przemocą. Emocjonalna narracja współbrzmi z subiektywnie opisywanymi sytuacjami chłopca, który zwykle (w szkole, w domu czy w drodze) czuje się niedoceniony, niezrozumiany, samotny i nieszczęśliwy. W przybliżeniu są to zabiegi w zakresie emocjonalnego przygotowania odbiorcy do przyjęcia perswazji.

Celem perswazji jest argumentowanie, jego literacki odpowiednik postrzegam w powieści Korczaka zarówno na poziomie idei (tzw. prawda dzieła), uogólnień trudnych doświadczeń dużych i matych, w takim samym stopniu wrażliwych na ból i samotność, spragnionych ciepła i bezpieczeństwa, jak i w podsumowujących zdarzenia krótkich wypowiedziach, przypominających sentencje:

Przyjemnie czasem coś dać ze swego, ale nie zawsze tylko brać i brać od starszych. Nieprzyjemnie, kiedy się dorosłemu chce podarować, a oni nie biorą albo dadzą co innego, co więcej warte. Zaraz zapłata. Poniżony się wtedy człowiek czuje jak żebrak (Korczak 1983: 144).

Myślałem w szarzyźnie dorosłego życia o barwnych latach dzieciństwa. Wróciłem, dałem się złudzić wspomnieniom. I oto wkroczyłem w szarzyznę dziecięcych dni i tygodni. Nic nie zyskałem, straciłem jeno hart rezygnacji (Korczak 1983: 212).

Stosowane obok argumentowania metaoperatory perswazyjne są środkami językowymi wzmacniającymi nakłaniającą funkcję komunikatu (por. Habrajska 2005: 117-119), zalicza się tu m.in. przywołanie obiegowej opinii, powołanie się na powszechność („,każdy wie”, ,jak wiadomo", ,jak sama nazwa wskazuje”, ,już wszyscy wiedzą, że” itd.) i właśnie zbliżone do tego typu metaoperatorów środki występują w analizowanej powieści.

„Narracja nie jest prostym, chronologicznym opisem wydarzeń. Na plan pierwszy wysuwa osobę narratora, jest opowieścią z jego punktu widzenia, zawiera w sobie uza- 
sadnienia, dlaczego warta jest opowiedzenia. Dlatego obok opisu tego, co się wydarzyło, zawiera w sobie emocje, myśli i interpretacje. Narrator to albo aktor, albo zainteresowany obserwator czyichś działań" (Nowak-Dziemianowicz 2014: 12). Kiedy znów będę maty obrazuje niejednolitość języka i narracji - rozpoznawalny jest patos (jako styl pisania podkreślający wzniosłość tematu) obok potoczności, emocjonalności; styl zobiektywizowany przy jednoczesnym występowaniu przekazu skoncentrowanego na szczegółach, na tym, co niepozorne, niezauważalne, co tworzy intymny świat narratora-bohatera, sferę jego subiektywności. W ten sposób budowany jest dziecięcy sposób ujmowania świata - uwaga skupia się na szczególe i emocjach. Poszerza się pole narracji: od opowieści o zdarzeniu, często bardzo wąttym fabularnie (jak chowanie i szukanie w domu lalki przez rodzeństwo) do uogólnionych refleksji, np. o ludzkim dążeniu do poznania, marności codziennych zabiegów, odmienności ocen i wartościowania. Niekiedy uwagi są zabarwione ironią, sarkazmem, tak charakterystycznymi dla stylu Korczaka.

\section{Refleksje końcowe}

„Literatura staje się swoistym laboratorium, w którym sprawdzane są granice ludzkiego człowieczeństwa”, jak powie Zofia Agnieszka Kłakówna (cyt. za: Włodarczyk 2014: 35). Zastosowanie w analizie wybranego tekstu literackiego Korczaka kategorii perswazyjności sytuuje działania badawcze w perspektywie pedagogicznej i teoretycznoliterackiej, a jednocześnie przecina się ze zderzeniem perspektywy dorosłego i dziecka. $\mathrm{W}$ wielowątkowych rozważaniach o narracji w pedagogice Mirosława Nowak-Dziemianowicz zwraca uwagę na „ważne pytania o to: czyją historię opowiadamy, jak ją opowiadamy i jak reprezentujemy tych, których historię opowiadamy" (Nowak-Dziemianowicz 2014: 13). Tekst Korczaka jest przykładem głosu, jakiego narrator udziela tym, którzy głosu nie mają, czyli dzieciom. Widoczne jest reprezentowanie dzieci niejako od wewnattrz, czemu służy specyficzna konstrukcja narratora-bohatera dziecięcego ze świadomością/ odpowiedzialnością dorosłego. Zauważalny jest wielogłos narratora. Całość obrazuje próbę wejścia w doświadczenia dziecka, w jego świat, by upomnieć się o dziecięce prawa. Pisząc o podwojonym narratorze, nie sposób pominąć uwagi Grzegorza Leszczyńskiego o strategii narracyjnej opartej na zderzeniu odczytań tej powieści: „(...) obu swych zakładanych odbiorców - dziecko i dorosłego - zmusza Korczakowski narrator do przyjęcia perspektywy usytuowanej kontrapunktowo względem własnych doświadczeń życiowych, wiekowych, osobistych, ontologicznych" (Leszczyński 2013: 89).

W świetle lektury tekstów Korczaka wydaje się uprawnione przypisanie mu motywacji, że należy tak pisać, aby zmieniać świat, oraz wiary, że jest to możliwe. Rolą pedagoga jest „,[o]pisać, wyjaśnić, zrozumieć po to, aby ten świat uczynić bardziej przyjaznym dla tych, którzy są w nim poddani jakiejś opresji, jakieś symbolicznej, zakorzenionej w kulturze przemocy (...)" (Nowak-Dziemianowicz 2014: 10). Przeprowadzona analiza jednostkowego tekstu literackiego Janusza Korczaka ukazuje konstruowanie narracji podporządkowane wspólnemu celowi, jakim jest przekonanie odbiorcy/czytelnika do racji 
narratora: równocześnie dziecka i dorosłego, obrońcy praw dzieci i podmiotu tychże praw. Tezy formułowane w różnych stylach oraz za pomocą oszczędnych, a jednocześnie trafnie dobranych środków wzajemnie się dopełniają.

\section{Literatura}

Bralczyk J. (2004), Język na sprzedaż, czyli o tym, jak język stuży reklamie i jak reklama używa języka. Gdańsk, Gdańskie Wydawnictwo Psychologiczne.

Dobrzyńska T. (2001), Tekst. W: J. Bartmiński (red.), Wspótczesny język polski. Lublin, Wydawnictwo UMCS

Eco U. (1994), Dzieło otwarte. Forma i nieokreśloność w poetykach wspótczesnych. Warszawa, Czytelnik.

Eco U. (1995), Sześć przechadzek po lesie fikcji. Kraków, Znak.

Głowiński M. (1977), Style odbioru. Szkice o komunikacji literackiej. Kraków, Wydawnictwo Literackie.

Głowiński M. (1998), Wirtualny odbiorca w strukturze utworu poetyckiego. W: M. Głowiński, Dzieto wobec odbiorcy. Szkice z komunikacji literackiej. Kraków, Universitas.

Habrajska G. (2005), Naktanianie, perswazja, manipulacja językowa. „Acta Universitatis Lodziensis. Folia Litteraria Polonica", 7.

http://bazhum.muzhp.pl/media/files/Acta_Universitatis_Lodziensis_Folia_Litteraria_Polonica/ Acta_Universitatis_Lodziensis_Folia_Litteraria_Polonica-r2005-t7-n2/Acta_Universitatis Lodziensis_Folia_Litteraria_Polonica-r2005-t7-n2-s91-126/Acta_Universitatis_Lodziensis Folia_Litteraria_Polonica-r2005-t7-n2-s91-126.pdf, 8.04.2019.

Handke R. (1982), Utwór fabularny w perspektywie odbiorcy. Wrocław, Zakład Narodowy im. Ossolińskich.

Grabias S. (2003), Język w zachowaniach społecznych. Lublin, Wydawnictwo UMCS.

Korczak J. (1983), Kiedy znów będę mały. Warszawa, Nasza Księgarnia.

Korczak J. (2012), Jak kochać dziecko. Dziecko w rodzinie. Warszawa, Rzecznik Praw Dziecka. http://brpd.gov.pl/sites/default/files/jak_kochac_dziecko_dziecko_w_rodzinie.pdf, 8.04.2019.

Korolko M. (1990), Sztuka retoryki. Warszawa, PWN.

Laskowska E. (red.) (1999), Skuteczność słowa w działaniach politycznych i społecznych. Bydgoszcz, Wydawnictwo Wyższej Szkoły Pedagogicznej.

Leszczyński G. (2013), Dialektyka ról czytelniczych w prozie Korczaka. W: A.M. Czernow (red.), Janusz Korczak. Pisarz. Warszawa, Stowarzyszenie Bibliotekarzy Polskich.

Lewiński P.H. (2001), Granice perswazji. W: G. Habrajska (red.), Język w komunikacji. T. 1. Łódź, Wydawnictwo Akademii Humanistyczno-Ekonomicznej.

Lisowska-Magdziarz M. (2006), Analiza tekstu w dyskursie medialnym. Kraków, Wydawnictwo Uniwersytetu Jagiellońskiego.

Lubaś W. (2006), Język w komunikacji, w perswazji i w reklamie. Dąbrowa Górnicza, Wyższa Szkoła Biznesu.

Mitosek Z. (1983), Teorie badań literackich. Warszawa, PWN.

Mosiołek-Kłosińska K., Zgółka T. (red.) (2003), Język perswazji publicznej. Poznań, Wydawnictwo Poznańskie. 
Nowak-Dziemianowicz M. (2014), Narracja w pedagogice - znaczenie, badania, interpretacje. „Kultura i Edukacja”, 2(102). http://www.kultura-i-

edukacja.pl/ojs/index.php?journal=kie\&page=article\&op=view\&path\%5B\%5D=298, 9.04.2019.

Rewers E. (1997), Granice etyki interpretacji. „Teksty Drugie”, 6. http://tekstydrugie.pl/wp-content/ uploads/2016/06/b87d18be3b2a0340aa50ccd409ca75ef.pdf, 9.04.2019.

Tokarz M. (2003), Argumentacja i perswazja. „Filozofia Nauki”, 11(1). http://bazhum.muzhp.pl/ media//files/Filozofia_Nauki/Filozofia_Nauki-r2003-t11-n1/Filozofia_Nauki-r2003-t11-n1s7-41/Filozofia_Nauki-r2003-t11-n1-s7-41.pdf, 9.04.2019.

Wierzbicka A. (1969), Dociekania semantyczne. Wrocław, Zakład Narodowy im. Ossolińskich.

Włodarczyk A. (2014), Etyka interpretacji tekstu literackiego. Postmodernizm. Humanizm. Dydaktyka. Kraków, Wydawnictwo Uniwersytetu Jagiellońskiego. 